\title{
Spices as natural additives for beef burger production
}

\author{
Juliana SEDLACEK-BASSANI ${ }^{1 *}$ (D), Thiago Luís Magnani GRASSI ${ }^{1}$, Juliana Campos Pereira DINIZ ${ }^{1}$, \\ Elisa Helena Giglio PONSANO ${ }^{1}$
}

\begin{abstract}
This study aimed to investigate if the inclusion of different spices in bovine burger affects bacterial growth, lipid oxidation and sensorial characteristics of the products. Four hamburger formulations were prepared: control (without additives), saffron (1\%), ginger $(1 \%)$ and urucum (1\%). The products were analyzed for total bacterial count (TBC) on days 0,7 and 15 (storage at $4{ }^{\circ} \mathrm{C}$ ) and 0,15 and 60 (storage at $-30^{\circ} \mathrm{C}$ ) and, for rancidity, on days 0,30 and 60 (storage at $-30^{\circ} \mathrm{C}$ ). The acceptance of the sensory attributes and the purchase intent were evaluated using hedonic scales. All burgers formulated with spices and kept at $4{ }^{\circ} \mathrm{C}$ had lower TBC than the control formulation, whereas for those stored at $-30^{\circ} \mathrm{C}$, the same occurred only with the ginger-made ones. Lower lipid oxidation was found for the formulations containing the spices. Control and ginger formulations led the acceptance of the tasters for the attributes appearance and color, besides that, aroused greater interest in the purchase intention trial. It was concluded that the addition of spices reduced TBC and delayed the lipid oxidation of hamburgers, and that the products elaborated with ginger had the highest sensory acceptance and purchase intention indexes.
\end{abstract}

Keywords: curcuma; ginger; Bixa orellana; bacterial load; chemical oxidation; consumer behavior.

Practical Application: Burger development with natural additives.

\section{Introduction}

The progress experienced in meat industrialization and the raise on the social and economic status of the population in the last years concurred to an increase in the consumption of meat products well as in its quality requirement (Madruga et al., 2004; Ramos \& Gomide, 2007). Synthetic additives are intentionally added to food during production or processing to improve organoleptic quality and/or to prevent deterioration (Péret-Almeida et al., 2008; Ramalho \& Jorge, 2006). Although food additives impart technological advantages to food, a concern about risks associated with their consumption remains, like allergic reactions, carcinogenicity, and behavioral disorders, such as hyperactivity (Agência Nacional de Vigilância Sanitária, 1999; Honorato et al., 2013; Zheng \& Wang, 2001).

Today's consumers look for healthier and more practical meat products, preferably with no synthetic chemical additives but still with pleasant and attractive color and taste and it rests to the food technologists the challenge to develop new products to meet that demand (Guimarães et al., 2010; Ramos \& Gomide, 2007; Sales et al., 2015; Varela \& Fiszman, 2013). The gourmet burger has attracted great consumer interest as it is made with fresh and tasty ingredients and maintains the nutritional value and convenience in the preparation (Oliveira et al., 2013; Souza et al., 2012).

However, hamburgers are subject to deterioration, mostly due to the action of microorganisms and to lipid oxidation, which may occur during processing and / or storage. The use of natural additives containing phenolic compounds and carotenoids seems to be promising to refrain these deterioration processes in foods (Bierhals et al., 2009; Cao et al., 2009; Garcia et al., 2012).

To this end, spices like saffron, ginger, annatto, cloves, cinnamon, rosemary and oregano are referred to make safer food products and of longer shelf life have (Martínez-Tomé et al., 2001; Semwal et al., 2015; Shan et al., 2007; Zhang et al., 2016). Thus, the aim of this study was to evaluate the effects of saffron, ginger and urucum on the microbial load and the lipid oxidation of bovine hamburgers prepared with these spices.

\section{Material and methods}

\subsection{Experimental design}

A completely randomized design with 3 replicates in a $3 \times 4$ factorial arrangement was used. The factors studied were: three storage periods $(0,7$ and 15 days for refrigerated burgers and 0,15 and 60 days for frozen burgers for the microbial count and 0,30 and 60 days for the lipid oxidation analysis) and four burger formulations [control, composed of a base formulation without additives (Table 1) and three other formulations, added with saffron, ginger and urucum spices].

\subsection{Burgers preparation}

Antisepsis of utensils and surfaces used for the preparation of the burgers was performed with $70 \%$ alcohol. Handlers had their hands washed and used disposable gloves and caps during the preparation (Agência Nacional de Vigilância Sanitária, 2004). 
The ingredients used for the elaboration of the hamburgers base formulation had recognized quality and were purchased in the local trade. The beef used had the seal of the Federal Inspection Service and was ground twice in an industrial grinder; the extra-virgin olive oil (O-Live) had maximum acidity of $0.2 \%$. Powdered saffron (Curcuma longa $\mathrm{L}$ ) and ginger (Zingiber officinale Roscoe) were purchased in the pure form in the local trade specialized in natural products (Temperos \& Arte) and the urucum (Bixa orellana L.) seeds were harvested from a tree located at the Faculty (fruits, leaves and flowers were botanically authenticated in the Department of Botany - IB UNESP - Botucatu), oven-dried for $72 \mathrm{~h}$ at $40{ }^{\circ} \mathrm{C}$ and ground in an industrial mill before use.

For the base formulation, the breads were moistened with potable water (approximately $700 \mathrm{ml}$ ) for about 30 minutes, pressed to remove water and mixed with the ground beef, the olive oil and the salt. The definition of the spices concentration was based on a preliminary sensorial analysis. The spices were added to the mixture according to the treatments, at $1 \%(\mathrm{w} / \mathrm{w})$, and the final mixture was pressed and shaped manually. The burgers were individually wrapped in polyethylene film, then a portion of them was stored for 15 days at $4{ }^{\circ} \mathrm{C}$ and another portion was stored for 60 days at $-30{ }^{\circ} \mathrm{C}$.

\subsection{Microbiological analysis}

Total bacteria (viable facultative aerobic and anaerobic mesophilic bacteria) were counted by the plating method in PCA (Plate Count Agar) and the results were expressed in log of the Colony Forming Units (CFU), as described by Downes \& Ito (2001). The analyzes were performed immediately after the burgers were prepared and repeated after 7 and 15 days of storage at $4{ }^{\circ} \mathrm{C}$ and after 15 and 60 days of storage at $-30^{\circ} \mathrm{C}$.

\subsection{Lipid oxidation}

Ten $\mathrm{g}$ of the hamburgers were homogenized with $50 \mathrm{ml}$ of $7.5 \%$ trichloroacetic acid in turrax for $1 \mathrm{~min}$. Then the mixture was filtered and $5 \mathrm{ml}$ of the filtrate were transferred to tubes containing

Table 1. Hamburger base formulation.

\begin{tabular}{lc}
\hline \multicolumn{1}{c}{ Ingredients } & Quantity \\
\hline Ground bovine meat & $1000 \mathrm{~g}$ \\
Bread (French type) & $140 \mathrm{~g}$ \\
Salt & $20 \mathrm{~g}$ \\
Extra-virgin olive oil & $10 \mathrm{~L}$ \\
\hline
\end{tabular}

$5 \mathrm{ml}$ of $0.02 \mathrm{M}$ thiobarbituric acid. The tubes were heated in a boiling water bath for 40 minutes and cooled in running water for 10 minutes for the quantification of the thiobarbituric acid reactive substances (TBARS) by spectrophotometry at $538 \mathrm{~nm}$. Values were expressed as mg of malonaldehyde / $\mathrm{kg}$ of sample. The analyzes were performed soon after the burgers were made and repeated after 30 and 60 days of storage at $-30{ }^{\circ} \mathrm{C}$.

\subsection{Sensory analysis}

The affective sensory analysis of the hamburgers (appearance, aroma, color, taste and texture) was performed with 43 untrained panelists, regular consumers of hamburgers. Prior to the assessment, the subjects were informed about the objectives and methods of the research and signed an Informed Term of Consent. The procedures were approved by the local Ethics Committee on Human Research (Opinion CEP 2.440.503).

The grilled samples identified with three random digits were presented to the panelists in white disposable dishes and the subjects were asked to rate the samples on the basis of a 5 -point hedonic scale (5 = "strongly liked", 4 = "moderately liked", 3 = "indifferent", 2 = "moderately disliked" and 1 = "strongly disliked") (Minin, 2013). Mineral water and cream cracker biscuits were available as neutralizers between samples in order to avoid carryover effects.

The purchase intention was also evaluated using a 5-point hedonic scale ( 5 = "certainly would buy", 4 = "probably would buy", 3 = "may buy/may not buy", 2 = "probably would not buy", 1 = "certainly would not buy") and the scores obtained were classified as: "rejection" (1 and 2); "indifference (3)" and "acceptance" (4 and 5).

\subsection{Statistical analysis}

Data on microbiological and lipid oxidation assays were analyzed by ANOVA, followed by t test when appropriate $(\mathrm{p}<0.05)$ and data from the sensory analysis were assessed with Friedman test followed by Simes-Hochberg test when appropriate $(\mathrm{p}<0.05)$. The data were analyzed using the Statistical Analyses System (SAS) 2012.

\section{Results and discussion}

\subsection{Microbiological analysis}

The interaction between the formulations and the storage periods under refrigeration (Table 2) was not statistically significant $(\mathrm{p}=0.196)$ regarding to the total bacteria count $(\mathrm{TBC})$.

Table 2. Means ( \pm standard deviations) of the total bacterial counts $(\log \mathrm{CFU} * / \mathrm{g})$ in the refrigerated burgers.

\begin{tabular}{|c|c|c|c|c|}
\hline \multirow{3}{*}{ Formulations } & \multicolumn{4}{|c|}{ Refrigeration $\left(4^{\circ} \mathrm{C}\right)$} \\
\hline & \multicolumn{3}{|c|}{ Storage period (days) } & \multirow{2}{*}{ Means } \\
\hline & 0 & 7 & 15 & \\
\hline Control & $7.20 \pm 0.00$ & $9.88 \pm 0.11$ & $9.98 \pm 0.02$ & $9.02^{\mathrm{a}} \pm 1.41$ \\
\hline Saffron & $6.89 \pm 0.22$ & $9.32 \pm 0.01$ & $9.18 \pm 0.19$ & $8.46^{\mathrm{c}} \pm 1.23$ \\
\hline Ginger & $6.78 \pm 0.31$ & $9.09 \pm 0.05$ & $9.50 \pm 0.03$ & $8.45^{\mathrm{c}} \pm 1.32$ \\
\hline Urucum & $7.04 \pm 0.00$ & $9.46 \pm 0.24$ & $9.58 \pm 0.18$ & $8.69^{b} \pm 1.29$ \\
\hline Means & $6.98^{b} \pm 0.22$ & $9.44^{\mathrm{a}} \pm 0.32$ & $9.56^{\mathrm{a}} \pm 0.32$ & - \\
\hline
\end{tabular}

${ }^{\star} \mathrm{CFU}=$ Colony Forming Unity. Means with the same letter do not differ statistically in both rows and columns at $5 \%$ significance. 
Refrigeration increases the lag phase of the microbial growth and thus increases the shelf life of food (Madigan et al., 2016). However, after a period of adaptation to low temperatures, the microbial growth resumes, albeit at a slower rate (Tortora et al., 2012), as it was observed in the present study.

All burgers containing natural additives had lower TBC than the control formulation, thus demonstrating the bactericidal effect of these spices (Table 2). In addition, the ginger and saffron burgers had lower TBC than the urucum burgers, when the storage temperature was $4^{\circ} \mathrm{C}$. Mancini et al. (2017a) also detected a delay on the TBC of pork burgers added of powdered ginger at $1 \%$ and $2 \%$ and stored at $4{ }^{\circ} \mathrm{C}$ for 7 days.

The interaction between the formulations and the storage periods under freezing also was not statistically significant $(p=0.460)$ regarding to TBC (Table 3$)$. Freezing makes microbial metabolism infeasible by preventing enzymatic activity and limiting water activity in foods and may even cause cell death due to temperature-induced injuries (Archer, 2004; Fellows, 2006; Forsythe, 2013). That was probably the case in the present study, since the lowest TBC was found with 60 days of storage (Table 3 ). This effect was potentiated by the presence of ginger in the hamburger formulation, which confirmed the antimicrobial action of the spice, as already described in the literature (Yadav et al., 2012).

The antimicrobial effect of the spices can be attributed to phenolic compounds like curcumin, bisdemethoxycurcumin, demethoxycurcumin, gingerols (saffron) and shogaols (ginger) (Brasil, 2015; Péret-Almeida et al., 2008; Semwal et al., 2015), and to carotenoids like bixin and norbixin (urucum) (Galindo-Cuspinera \& Rankin, 2005; Garcia et al., 2012; Mercadante \& Pfander, 2001; Tocchini \& Mercadante, 2001).

It is recognized that the antimicrobial activity of phenolic compounds may involve multiple modes of action, such as breakage of the cell wall, rupture of the cytoplasmic membrane with leakage of cellular components, alteration of fatty acid constituents and membrane phospholipids, and influence on DNA and RNA synthesis with (Shan et al., 2007; Zhang et al., 2016).

\subsection{Lipid oxidation}

A significant interaction $(\mathrm{p}=0.0064)$ between the hamburger formulations and the storage periods under freezing was detected (Table 4). The use of the spices guaranteed the lowest TBARS with 0,30 and 60 days of storage, which means an important result once the shelf life of frozen hamburger 60 days.

More than bringing undesirable organoleptic characteristics to foods, lipid oxidation causes the loss of nutrients and the production of compounds harmful to human health, thus impairing the nutritional value (Ansorena \& Astiasarán, 2004; Germano \& Germano, 2001; Koblitz, 2011). Besides that, temperature is not able to inhibit the reaction, which may increase during frozen storage (Fellows, 2006), as it occurred in the experiment.

These results demonstrate the effectiveness of the spices also as antioxidants and indicate that their phenolic compounds and carotenoids may be used as an alternative to synthetic antioxidants (Del Ré \& Jorge, 2012; Georgantelis et al., 2007; Karre et al., 2013). Due to their oxidation-reduction properties, the phenolic compounds play an important role in the absorption and neutralization of free radicals (Zheng \& Wang, 2001) and also are able to chelate metal ions, so disrupting the propagation phase of the lipid oxidation reaction (Degáspari \& Waszczynskyj, 2004). The conjugated double bonds in the carotenoids structures render them antioxidant properties, acting as quenchers of singlet oxygen and scavengers of other reactive oxygen species, both in vivo an in vitro. So, the use of carotenoids containing spices in food formulations might also bring benefits to the consumers since the adequate carotenoid supplementation may significantly reduce the risk of several disorders mediated by reactive oxygen species (Edge et al., 1997; Fiedor \& Burda, 2014).

Table 3. Means ( \pm standard deviations) of the total bacterial counts (log CFU */g) in the frozen burgers.

\begin{tabular}{|c|c|c|c|c|}
\hline \multirow{3}{*}{ Formulations } & \multicolumn{4}{|c|}{ Freezing $\left(-30^{\circ} \mathrm{C}\right)$} \\
\hline & \multicolumn{3}{|c|}{ Storage period (days) } & \multirow{2}{*}{ Means } \\
\hline & 0 & 15 & 60 & \\
\hline Control & $7.16 \pm 0.06$ & $6.75 \pm 0.05$ & $6.45 \pm 0.15$ & $6.79^{a} \pm 0.33$ \\
\hline Saffron & $6.70 \pm 0.01$ & $6.52 \pm 0.15$ & $6.05 \pm 0.01$ & $6.43^{\mathrm{ab}} \pm 0.31$ \\
\hline Ginger & $6.34 \pm 1.00$ & $6.83 \pm 0.05$ & $6.02 \pm 0.03$ & $6.40^{\mathrm{b}} \pm 0.58$ \\
\hline Urucum & $7.10 \pm 0.10$ & $6.77 \pm 0.04$ & $6.24 \pm 0.04$ & $6.70^{\mathrm{ab}} \pm 0.39$ \\
\hline Means & $6.83^{\mathrm{a}} \pm 0.52$ & $6.72^{\mathrm{a}} \pm 0.14$ & $6.19^{b} \pm 0.19$ & - \\
\hline
\end{tabular}

${ }^{\star} \mathrm{CFU}=$ Colony Forming Unity. Means with the same letter do not differ statistically in both rows and columns at $5 \%$ significance.

Table 4. Influence of the formulations on the burgers lipid oxidation.

\begin{tabular}{|c|c|c|c|}
\hline \multirow{3}{*}{ Formulations } & \multicolumn{3}{|c|}{ TBARS (mg of malonaldehyde /kg) } \\
\hline & \multicolumn{3}{|c|}{ Storage period (days) } \\
\hline & 0 & 30 & 60 \\
\hline Control & $0.174 \pm 0.011^{\mathrm{c}}$ & $0.202 \pm 0.018^{b}$ & $0.255 \pm 0.023^{\mathrm{a}}$ \\
\hline Saffron & $0.154 \pm 0.008^{c}$ & $0.157 \pm 0.018^{\mathrm{c}}$ & $0.163 \pm 0.007^{c}$ \\
\hline Ginger & $0.120 \pm 0.008^{\mathrm{d}}$ & $0.117 \pm 0.009^{d}$ & $0.153 \pm 0.018^{c}$ \\
\hline Urucum & $0.125 \pm 0.015^{\mathrm{d}}$ & $0.153 \pm 0.018^{c}$ & $0.160 \pm 0.009^{c}$ \\
\hline
\end{tabular}

TBARS - Thiobarbituric Acid Reactive Substances. Means with the same letter do not differ statistically at $5 \%$ significance. 
Antioxidant activity in camel and tilapia meat hamburgers prepared with ginger and urucum extracts has also been described in the literature (Abdel-Naeem \& Mohamed, 2016; Meleiro et al., 2013) well as in pork and rabbit burgers prepared with ginger powder and refrigerated at $4{ }^{\circ} \mathrm{C}$ for 7 days (Mancini et al., 2017a; Mancini et al., 2017b).

\subsection{Sensory analysis}

Ginger and control burgers headed the tasters acceptance regarding to appearance and color, which are decisive sensory attributes for the buying decision (Figure 1). This preference was confirmed by the higher scores assigned to the same formulations in the purchase intention survey (Figure 2) and this result was explained by the color similarity between ginger and control formulations. Aroma and flavor did not differ between treatments and the final texture of the burgers was not influenced by the type of spice (Figure 1).

The main objective of the sensory analysis is to study the perceptions, sensations and reactions of the consumer to the characteristics of the products, including their acceptance or rejection and represents an important tool for the food industry, especially in the development of new products (Minin, 2013; Ramos \& Gomide, 2007). The lower grades received by the saffron and urucum formulations for appearance, color and purchase intent (Figures 1 and 2) demonstrated that the consumers are used to standard formulations and resists novelties such as the color

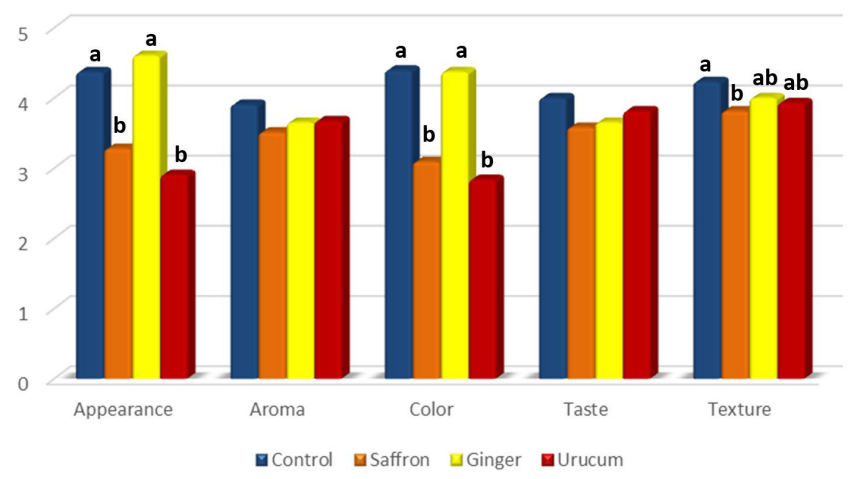

Figure 1. Sensory analysis of the experimental burgers. Different letters indicate significant difference in columns.

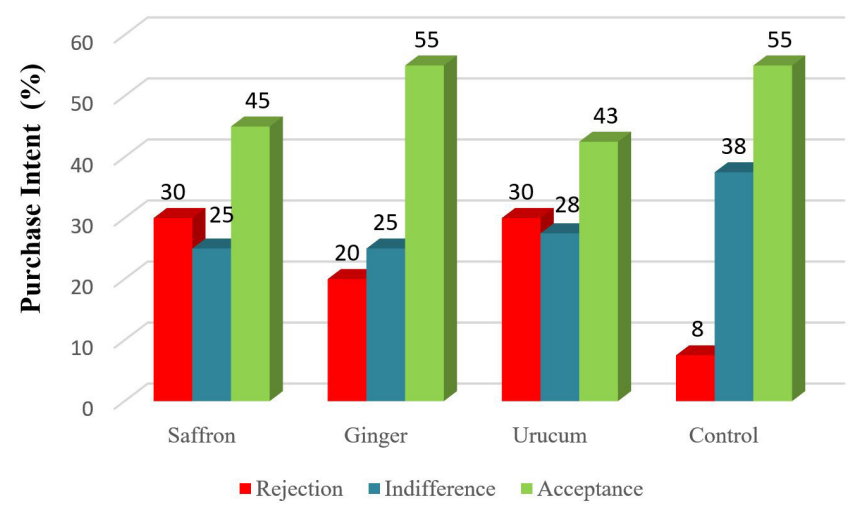

Figure 2. Purchase intent of the experimental burgers. that came up from the carotenoids in the spices. The disapproval of saffron and urucum burgers was associated to the colors of the products, referred as "deteriorated" and "raw", respectively, by the panelists.

Other authors also found high sensory acceptance for burgers prepared with ginger and different types of meat (Abdel-Naeem \& Mohamed, 2016; Mancini et al., 2017a).

Among the spices tested in this experiment, ginger showed up the best one for controling microbial growth and lipid rancidity and attained the highest sensory acceptance, which makes it the spice of choice to be used as a natural additive in the elaboration of beef hamburgers.

\section{Conclusion}

The addition of the spices in the formulations reduced the microbial counts and slowed the lipid oxidation of the burgers. Moreover, the burgers made with ginger had the highest rates of sensory acceptance and purchase intent.

\section{References}

Abdel-Naeem, H. H. S., \& Mohamed, H. M. H. (2016). Improving the physico-chemical and sensory characteristics of camel meat burger patties using ginger extract and papain. Meat Science, 118, 52-60. http://dx.doi.org/10.1016/j.meatsci.2016.03.021. PMid:27045253.

Ansorena, D., \& Astiasarán, I. (2004). Effect of storage and packaging on fatty acid composition and oxidation in dry fermented sausages made with added olive oil and antioxidants. Meat Science, 67(2), 237-244. http://dx.doi.org/10.1016/j.meatsci.2003.10.011. PMid:22061319.

Agência Nacional de Vigilância Sanitária - ANVISA. (1999). Aditivos alimentares e coadjuvantes de tecnologia. Brasília: ANVISA. Retrieved from http://portal.anvisa.gov.br/alimentos/aditivos-alimentares

Agência Nacional de Vigilância Sanitária - ANVISA. (2004). Cartilha sobre boas práticas para serviços de alimentação: RDC No 216, de 15 de Setembro de 2004 (3. ed., p. 44). Brasília: ANVISA.

Brasil. Ministério da Saúde. Agência Nacional de Vigilância Sanitária. (2015). Monografia da espécie Curcuma longa L. (CURCUMA). Retrieved from http://portalarquivos2.saude.gov.br/images/pdf/2016/ fevereiro/22/Monografia-Curcuma-CP-corrigida.pdf

Archer, D. L. (2004). Freezing: an underutilized food safety technology? International Journal of Food Microbiology, 90(2), 127-138. http:// dx.doi.org/10.1016/S0168-1605(03)00215-0. PMid:14698095.

Bierhals, V. S., Machado, V. G., Echevenguá, W. O., Costa, J. A. V., \& Furlong, E. B. (2009). Compostos fenólicos totais, atividade antioxidante e antifúngica de multimisturas enriquecidas com a microalga Spirulina platensis. Revista do Instituto Adolfo Lutz, 68(1), 42-48.

Cao, L., Si, J. Y., Liu, Y., Sun, H., Jin, W., Li, Z., Zhao, X. H., \& Pan, R. L. (2009). Essential oil composition, antimicrobial and antioxidant properties of Mosla chinensis Maxim. Food Chemistry, 115(3), 801805. http://dx.doi.org/10.1016/j.foodchem.2008.12.064.

Degáspari, C. H., \& Waszczynskyj, N. (2004). Propriedades antioxidantes de compostos fenólicos. Visão Acadêmica, 5(1), 33-40.

Del Ré, P. V., \& Jorge, N. (2012). Especiarias como antioxidantes naturais: aplicações em alimentos e implicação na saúde. Revista Brasileira de Plantas Medicinais, 14(2), 389-399. http://dx.doi.org/10.1590/ S1516-05722012000200021.

Downes, F. P., \& Ito, K. (2001). Compendium of methods for the microbiological examination of foods (4th ed.). Washington: American Public Health Association. http://dx.doi.org/10.2105/9780875531755. 
Edge, R., Mcgarvey, D. J., \& Truscott, T. G. (1997). The carotenoids as anti-oxidants: A review. Journal of Photochemistry and Photobiology. B, Biology, 41(3), 189-200. http://dx.doi.org/10.1016/S10111344(97)00092-4. PMid:9447718.

Fellows, P. J. (2006). Tecnologia do processamento de alimentos: princípios e prática (2nd ed.). Porto Alegre: Artmed.

Fiedor, J., \& Burda, K.. (2014). Potential role of carotenoids as antioxidants in human health and disease. Nutrients, 6(2), 466-488. http://dx.doi. org/10.3390/nu6020466. PMid:24473231.

Forsythe, S. J. (2013). Microbiologia da segurança dos alimentos (2nd ed.). Porto Alegre: Artmed.

Galindo-Cuspinera, V., \& Rankin, S. A. (2005). Bioautography and chemical characterization of antimicrobial compound(s) in commercial water-Soluble annatto extracts. Journal of Agricultural and Food Chemistry, 53(7), 2524-2529. http://dx.doi.org/10.1021/ jf048056q. PMid:15796589.

Garcia, C. E. R., Bolognesi, V. J., Dias, J. F. G., Miguel, O. G., \& Costa, C. K. (2012). Carotenóides bixina e norbixina extraídos do urucum (Bixa orellana L.) como antioxidantes em produtos cárneos. Ciência Rural, 42(8), 1510-1517.

Georgantelis, D., Blekas, G., Katikou, P., Ambrosiadis, I., \& Fletouris, D. J. (2007). Effect of rosemary extract, chitosan and $\alpha$-tocopherol on lipid oxidation and colour stability during frozen storage of beef burgers. Meat Science, 75(2), 256-264. http://dx.doi.org/10.1016/j. meatsci.2006.07.018. PMid:22063657.

Germano, P. M. L., \& Germano, M. I. S. (2001). Higiene e vigilância sanitária de alimentos (2nd ed.). São Paulo: Varela.

Guimarães, R. R., Freitas, M. C. J., \& Silva, V. L. M. (2010). Bolos simples elaborados com farinha da entrecasca de melancia (Citrullus vulgaris, sobral): avaliação química, física e sensorial. Food Science and Technology (Campinas), 30(2), 354-363. http://dx.doi.org/10.1590/ S0101-20612010000200011.

Honorato, T. C., Batista E., Pires, T., \& Nascimento, K. O. (2013) Aditivos alimentares: aplicações e toxicologia. Revista Verde de Agroecologia e Desenvolvimento Sustentável, 8(5), 1-11.

Karre, L., Lopez, K., \& Getty, K. J. K. (2013). Natural antioxidants in meat and poultry products. Meat Science, 94(2), 220-227. http:// dx.doi.org/10.1016/j.meatsci.2013.01.007. PMid:23501254.

Koblitz, M. G. B. (2011). Matérias-primas alimentícias: composição e controle de qualidade. Rio de Janeiro: Guanabara Koogan.

Madigan, M. T., Martinko, J. M., Bender, K. S., Buckley, D. H., \& Stahl, D. A. (2016). Microbiologia de Brock. (14th ed.). Porto Alegre: Artmed.

Madruga, M. S., Figueiredo, M. J., Nunes, M. L., \& Lima, F. M. S. (2004). Teores de colesterol de linguiças de frango "light" e tradicionais submetidas a diferentes condições de estocagem. Food Science and Technology, 24(4), 527-531. http://dx.doi.org/10.1590/S010120612004000400008.

Mancini, S., Paci, G., Fratini, F., Torracca, B., Nuvoloni, R., Dal Bosco, A., Roscini, V., \& Preziuso, G. (2017a). Improving pork burgers quality using Zingiber officinale Roscoe powder (ginger). Meat Science, 129, 161-168. http://dx.doi.org/10.1016/j.meatsci.2017.03.004. PMid:28314171.

Mancini, S., Preziuso, G., Dal Bosco, A., Roscini, V., Parisi, G., \& Paci, G. (2017b). Modifications of fatty acids profile, lipid peroxidation and antioxidant capacity in raw and cooked rabbit burgers added with ginger. Meat Science, 133, 151-158. http://dx.doi.org/10.1016/j. meatsci.2017.07.003. PMid:28692848.

Martínez-Tomé, M., Jiménez, A. M., Ruggieri, S., Frega, N., Strabbioli, R., \& Murcia, M. M. (2001). Antioxidant properties of mediterranean spices compared with common food additivies. Journal of Food Protection, 64(9), 1412-1419. http://dx.doi.org/10.4315/0362028X-64.9.1412. PMid:11563520.
Meleiro, V. C., Cavalcante R., Nery, I. A., \& Barbosa, M. I. (2013). Elaboração da composição centesimal e avaliação da estabilidade oxidativa de hambúrgueres de tilápia-do-Nilo (Oreochromis niloticus Linnaeus, 1758), adicionados de carotenóides de Bixa orellana L. Perspectivas da Ciência e Tecnologia, 5(1-2), 18-26.

Mercadante, A. Z., \& Pfander, H. (2001). Caracterização de um novo carotenoide minoritário de urucum. Food Science and Technology, 21(2), 193-196. http://dx.doi.org/10.1590/S0101-20612001000200013.

Minin, V. P. R. (2013). Análise sensorial: estudos com consumidores (3rd ed., p. 332). Viçosa: UFV.

Oliveira, D. F., Coelho, A. R., Burgardt, V. C. F., Hashimoto, E. H., Lunkes, A. M., Marchi, J. F., \& Tonial, I. B. (2013). Alternativas para um produto cárneo mais saudável: uma revisão. Brazilian Journal of Food Technology, 16(3), 163-174. http://dx.doi.org/10.1590/S198167232013005000021.

Péret-Almeida, L., Naghetini, C. C., Nunan, E. A., Junqueira, R. G., \& Glória, M. A. B. (2008). Atividade antimicrobiana in vitro do rizoma em pó, dos pigmentos curcuminóides e dos óleos essenciais da Curcuma longa L. Ciência e Agrotecnologia, 32(3), 875-881. http:// dx.doi.org/10.1590/S1413-70542008000300026.

Ramalho, V. C., \& Jorge, N. (2006). Antioxidantes utilizados em óleos, gorduras e alimentos gordurosos. Revista Química Nova, 29(4), 755-760. http://dx.doi.org/10.1590/S0100-40422006000400023.

Ramos, E. M., \& Gomide, L. A. M. (2007). Avaliação da qualidade de carnes: fundamentos e metodologias. Viçosa: UFV.

Sales, P. V. G., Sales, V. H. G., \& Oliveira, E. M. (2015). Avaliação sensorial de duas formulações de hambúrguer de peixe. Revista Brasileira de Produtos Agroindustriais, 17(1), 17-23. http://dx.doi. org/10.15871/1517-8595/rbpa.v17n1p17-23.

Semwal, R. B., Semwal, D. K., Combrinck, S., \& Viljoen, A. M. (2015). Gingerols and shogaols: Important nutraceutical principles from ginger. Phytochemistry, 117, 554-568. http://dx.doi.org/10.1016/j. phytochem.2015.07.012. PMid:26228533.

Shan, B., Cai, Y. Z., Brooks, J. D., \& Corke, H. (2007). The in vitro antibacterial activity of dietary spice and medicinal herb extracts. International Journal of Food Microbiology, 117(1), 112-119. http:// dx.doi.org/10.1016/j.ijfoodmicro.2007.03.003. PMid:17449125.

Souza, V. L. F., Sasaki, J. Y., Franco, M. L. R. S., Barbosa, M. J. B., \& Cardozo, R. M. (2012). Processing, physicochemical, and sensory analyses of ostrich meat hamburger. Food Science and Technology, 32(3), 450-454. http://dx.doi.org/10.1590/S0101-20612012005000062.

Tocchini, L., \& Mercadante, A. Z. (2001). Extração e determinação, por CLAE, de bixina e norbixina em coloríficos. Food Science and Technology, 21(3), 310-313. http://dx.doi.org/10.1590/S010120612001000300010.

Tortora, G. J., Funke, B. R., \& Case, C. L. (2012). Microbiologia (10th ed.) Porto Alegre, Artmed.

Varela, P., \& Fiszman, S. M. (2013). Exploring consumers' knowledge and perceptions of hydrocolloids used as food additives and ingredients. Food Hydrocolloids, 30(1), 477-484. http://dx.doi.org/10.1016/j. foodhyd.2012.07.001.

Yadav, S., Rai, N., Verma, A. K., \& Sharma, R. K. (2012). Zingiber officinale Rosc.: A monographic review research \& reviews. Le Journal de Botanique, 1(1), 45-50.

Zhang, H., Wu, J., \& Guo, X. (2016). Effects of antimicrobial and antioxidant activities of spice extracts on raw chicken meat quality. Food Science and Human Wellness, 5(1), 39-48. http://dx.doi. org/10.1016/j.fshw.2015.11.003.

Zheng, W., \& Wang, S. Y. (2001). Antioxidant activity and phenolic compounds in selected herbs. Journal of Agricultural and Food Chemistry, 49(11), 5165-5170. http://dx.doi.org/10.1021/jf010697n. PMid:11714298. 